\title{
Biodegradability of Low Density Polyethylene Containing Biodegradation-inducing Agents. Biodegradation in Soil for 13 Years
}

Tomoko WATANABE*1, , Yoshito OHTAKE*1, Hitoshi ASABE*2, Fumio KOYAMA ${ }^{* 3}$, Nobunao MURAKAMI ${ }^{* 4}$, Mutsuhisa FURUKAWA ${ }^{* 5}{ }^{* 1}$; Chemicals Evaluation and Research Institute, Japan, 1600 Shimotakano, Sugito-machi, Kitakatsushika-gun, Saitama, 345-0043, Japan, ${ }^{* 2}$; Hagihara Industries, Inc., 1-4 Mizushima Nakadori, Kurashiki, Okayama, 712-8072, Japan, ${ }^{* 3}$; ITOCHU Co., 2-5-1 Kita-Aoyama, Minato-ku, Tokyo, 107-0061, Japan, ${ }^{* 4}$; Takenaka Co., 1-5-1 Otsuka, Inzai, Chiba, 270-1395, Japan, ${ }^{* 5}$; Graduate School of Science and Technology, Nagasaki University, 114 Bunkyo-machi, Nagasaki, 852-8521, Japan)

Biodegradation of low density polyethylene (LDPE) containing biodegradation-inducing agents was carried out in soil for 13 years. When LDPE containing biodegradation-inducing agents composed of starch, vegetable oil, calcium oxide, metal compounds, and oxidized wax were buried in soil for 13 years, biodegradation proceeded to some extent. The progress of degradation was monitored by the remaining weight, SEM, GPC and FT-IR measurement of the specimen. Differed from the ordinary oxidative degradation, formation of carbon-carbon double bond and hydroxy group together with carbonyl function was confirmed in the sample used in this study. Though the rate of biodegradation was still slow, the significant acceleration was observed by using the biodegradation-inducing agents compared with that of LDPE alone.

(Received on January 22, 2008) (Accepted on April 12, 2008)

Key Words : Low Density Polyethylene (LDPE), Soil, Biodegradation, Oxidative Degradation, Biodegradation inducing Agents

\section{1. 緒}

ポリエチレンはこれまで，低分子量成分を除き微生物分 解を受けないといわれてきた。しかし，30年間以上微生 物活性な土壤中に浅く埋没していた低密度ポリエチレン (LDPE) フィルムは，明らかに通常の酸化劣化とは異なる 特異的な酸化現象をともなう分解を示していることを報告 した ${ }^{1-3)}$.さらにこの分解途上のLDPEマルチフィルムお よび，周囲の土壤から LDPEを特異的に分解する能力を有 する微生物を集積振とう培養法により単離・同定を行った 結果, Bacillus circulans, Bacillus brevies, Bacillus sphaeri-

\footnotetext{
†本報を「LDPEの生分解性 (第 12 報)」とする.

${ }^{* 1}$ (財)化学物質評価研究機構

（厂 345-0043 埼玉県北葛飾郡杉戸町下高野 1600番地）

*2萩原工業株) ( ₹ 712-8072 倉敷市水島中通 1-4)

*3伊藤忠商事(秼) ( $\mathrm{T} 107-0061$ 東京都港区北青山 2-5-1)

$* 4$ (侏竹中工務店 ( 1 270-1395 印西市大塚 1-5-1) 技術研究所 副所長

*5 長崎大学大学院生産科学研究科 (T 852-8521 長崎市文教町 1-14)
}

cusの 3 種類を同定した ${ }^{4)}$ 。また，土㙵埋設による LDPE の酸化劣化部には, 土壤中の $\mathrm{Fe}, \mathrm{Al}$ などの元素の集中が 生じることを確認しており，これら金属化合物は，ポリマ 一の劣化初期に発生するヒドロペルオキシドをレドックス 反応により接触分解し, フリーラジカルの生成を促進化し ていると考察した ${ }^{1)}$ 。しかし，この微生物分解は一旦，酸 化劣化したLDPEが分解に相応しい環境下に入ることによ って, ゆっくりと進行するものの，その時間は他の生分解 プラスチックと比べて非常に遅い。

そこで我々は，LDPEの生分解を促進化するために，シ ランカップリング処理でんぷん, 酸化植物油などの生分解 誘引殽を開発し，LDPEに添加したフィルムを作製し，土 壤埋設試験を実施した。その結果，短期間でありながら， 部分的ではあるものの微生物分解することを見いだし1), 実用的な速度でLDPEを微生物分解させるためには, 分解 促進効果をもつ添加剤の配合が不可欠であることを提唱し た。 
これ以後多くの研究者が研究に取り組み，ポリ乳酸5), ポリカプロラクトン, エチレンーアクリル酸共重合体 ${ }^{6)}$, バナナデンプン ${ }^{7)}$ ， ポリ $(\beta \text { ヒドロキシブチレート })^{8)}$ 等 を分解誘引剤として報告している，Jakubowiczらは，酸 化促進剤としてステアリン酸マンガンを含む熱酸化劣化ポ リエチレンフィルムの好気的生分解度を求めるために，コ ンポスト条件下で処理し, 二酸化炭素発生量で評価してい $ろ^{9)}$. また, Khabbazらは, 分解可能マルチフィルムを設 計するために, LDPEへ酸化促進剤としてステアリン酸マ ンガン，スチレンーブタジエンゴムあるいは天然ゴムを添 加して酸化劣化度を評価している ${ }^{10)}$.

上述したように多くの生分解誘引剤が研究されている が，長期土壌埋設試験についての報告は皆無である.

本研究では, 生分解誘引剤マスターバッチ配合 $\mathrm{LDPE}^{1)}$ を1993年から土㙵埋設試験を行っている試験片について， 土壤埋設 3 年及び 13 年間の長期にわたる生分解進行状態 を調べ，生分解挙動を明らかにした。

\section{2. 実}

\section{験}

\section{1 長期土壤埋設用フィルムの作成}

結晶性の低いポリマーほど微生物によるダメージを受け やすいため11,12), ベースポリマーには結晶性の低い LDPEを選択した。具体的には, 生分解誘引剤によるポリ マーの酸化劣化の進行を早めるために酸化防止剂を含ま ず，かつ，ポリマー鎖末端からの exogeneous な微生物分 解反応 ${ }^{13)}$ を進行させるためにメルトインデックス $(\mathrm{MI})$ が 比較的高い低密度ポリエチレン（日本石油化学株式会社製 LDPE-F31N； MI = 2 ; 重量平均分子量 88,000)）を用い た.これに生分解誘引剤マスターバッチを $20 \mathrm{wt} \%$ 添加し, 厚さ $30 \mu \mathrm{m}$ のブロー成形フィルムを調製した. Table 1 に 生分解誘引剤添加フィルムの組成を示す.

\section{2 埋設土壤および埋設期間}

調製したフィルムを, 土壤の組成 (Table 2), 微生物の 種類と量 (Table 3，4) が把握されている微生物活性な堆肥 土壤 ${ }^{11)}$ に 1993 年 4 月から 1996 年 5 月までの 3 年間およ び，2006年 4 月までの 13 年間埋設した。また，比較試料 として生分解誘引剂無添加LDPEフィルムを同様に埋設し

Table 1 Composition of biodegradation-inducing agents-added LDPE

\begin{tabular}{lc}
\hline Compounding agents & Weight \% \\
\hline LDPE F31N* (Base polymer) & 84.6 \\
Starch (Induction of microbes) & 8.6 \\
Vegetable oil (Accelerator of oxidative degradation) & 1.2 \\
Calcium oxide (Agent of soak up water) & 1.6 \\
Metal compounds (Accelerator of oxidative degradation) & 3.0 \\
Oxidized wax (Accelerator of oxidative degradation) & 1.0 \\
\hline
\end{tabular}

*produced by NIPPON Petrochemicals co., Ltd. (Melt index $=2$, $M_{\mathrm{w}}=8.8 \times 10^{4}$ )
た. 試料の詳細が分かるようにフィルムの一辺をアルミニ ウムテープで覆い, 試料名を記入し, 更に切り込みを入れ て採取時に判別できるようにした，LDPEを分解する好気 性菌が多く分布している深さ $10 \mathrm{~cm}$ から $20 \mathrm{~cm}$ の比較的浅 い位置に埋設し，またBacillus 菌が多く付着し，なおかつ 地表面の乾燥を防ぐために無農薬にて栽培した稲ワラを埋 設土壤に被せた.

\section{3 生分解状況の評価}

\subsection{1 目視, デジタルマイクロスコープおよび走査型 電子顕微鏡(SEM)による外観観察}

生分解状況の外観観察は, 目視, デジタルマイクロスコ ープで行った。さらに, フッ化水素酸に 48 時間浸漬後, 蒸留水で洗浄し, 室温で真空乾燥させた試料を用いて $\operatorname{SEM}$ (日本電子製 JSM-5610LV, 加速電圧 $10 \mathrm{k} \mathrm{V}$, 高真 空モードにて倍率 150 ～10,000 倍) 観察により, 分解状況 や酵素分解跡, すなわち微生物による酵素分解の際に微生 物の体内に保有されている酵素が細胞壁を通して体外に代 謝され, 菌体形状をフィルム表面に写し出すボディーマー クの有無を確認した.

\section{3 .2 重量測定による分解度の算出}

測定試料には，付着した土壤成分を除去するために，蒸 留水中で超音波照射後, $1 / 10$ 希釈のフッ化水素酸に 48 時 間浸漬処理, 再び蒸留水洗浄, 室温で 48 時間真空乾燥後, シリカゲルを入れたデシケータ中に保管して用いた. 土壤 埋設期間 13 年の厚さ $30 \mu \mathrm{m}$ の生分解誘引剂添加フィルム が破片状であったため直径 $10 \mathrm{~mm}$ の円形に打ち抜いた試料 を, 単位面積当たりの重量測定による分解度の算出に使用 した. 比較試料には土壤埋設期間 13 年の厚さ $30 \mu \mathrm{m}$ の無

Table 2 Chemical analysis of compost soil

\begin{tabular}{lr}
\hline Active $\mathrm{pH}(\mathrm{pH})$ & 7.4 \\
Substitutive $\mathrm{pH}(\mathrm{pH})$ & 6.3 \\
Moisture content $(\%)$ & 157.2 \\
Water content $(\%)$ & 61.0 \\
Organic matter $(\%)$ & 13.9 \\
Inorganic matter $(\%)$ & 25.1 \\
\hline
\end{tabular}

Indicated in \% per fresh soil.

Table 3 The number of microorganisms in compost soil

\begin{tabular}{ll}
\hline Viable cell /g & $8.4 \times 10^{7}$ \\
Unaerobes /g & $1.0 \times 10^{6}$ \\
Clostridia /g & $1.8 \times 10^{5}$ \\
Mold /g & $2.0 \times 10^{4}$ \\
\hline
\end{tabular}

Indicated in numbers per fresh soil.

Table 4 Identification of microorganisms in compost soil

$$
\begin{aligned}
& \text { Clostridium sp. } \\
& \text { Proteus sp } \\
& \text { Bacillus sp. } \\
& \text { Penicillium sp. }
\end{aligned}
$$


添加LDPEフィルムを用いた。測定はそれぞれ3か所ずつ 行った.

\section{3 .3 高温ゲルパーメーションクロマトグラフィー (GPC)による分子量および分子量分布測定}

高温GPCにはウォーターズ社製 Alliance GPCV-2000を 用いて検出器 RI，カラム TSKgel GMH6-HT (内径 7.8

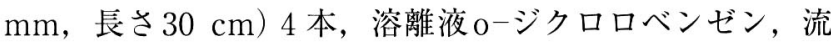
速 $1.0 \mathrm{~mL} /$ 分, カラム温度 $135{ }^{\circ} \mathrm{C}$ の条件で、較正試料とし て単分散ポリスチレンを使用し測定した。重量測定と同様 にフッ化水素酸浸漬処理を行い，蒸留水洗浄，室温で 48 時間真空乾燥した試料を o-ジクロロベンゼン $(0.5 \mathrm{mg} / \mathrm{mL})$ に $135{ }^{\circ} \mathrm{C}$ で溶解し $1 \mu \mathrm{m}$ ガラスフィルターで高温ろ過後, 測定に供した。

\section{3 .4 顕微フーリエ変換赤外分光法(FTーIR)による官 能基の同定}

バイオ・ラッドラボラトリーズ社製 DIGILAB FTS-6000 と付属の赤外顕微鏡 UMA-500を用いて顕微 A T R 法 (ATRプリズムにはゲルマニウム結晶を使用)，分解能 8.0 $\mathrm{cm}^{-1}$, スキャン回数 256 回で分析し, 主鎖中の炭素 - 炭 素二重結合 $\left(1640 \mathrm{~cm}^{-1}\right)$ ，通常の酸化劣化で生じる 1720 $\mathrm{cm}^{-1}$ 付近のカルボニル基（ケトンおよびカルボン酸），ア ルコール由来の - $\mathrm{OH}$ 変角振動 $\left(1080 \mathrm{~cm}^{-1}\right)$, 通常の - $\mathrm{OH}$ 伸縮振動 $\left(3400 \mathrm{~cm}^{-1}\right)$ の吸収 ${ }^{2,14)}$ を確認した。

顕微 FT-IR 分析用試料には，重量測定と同様にフッ化 水素酸浸漬処理で土壤成分を除去後，分解途上のフィルム
に付着している微生物から代謝された酵素等を除去するた め, Lysis Buffer $(4 \%(\mathrm{w} / \mathrm{v})$ CHAPS $\{3-(3-$ cholamidopropyl) dimethylammonio-1-propanesulfonate , $2 \mathrm{M}$ チ オウレア， $8 \mathrm{M}$ ウレア，10 mMトリス一塩酸緩衝液 $\mathrm{pH}$ 8.8)に18 時間室温浸漬，超音波照射後，蒸留水で洗浄， 更にタンパク質分解酵素溶液(トリプシン $1.0 \mathrm{mg}+50$ $\mathrm{mM}$ 炭酸アンモニウム $10 \mathrm{~mL}) に 37{ }^{\circ} \mathrm{C}$ ，48時間浸漬，蒸 留水で洗浄, 室温で 48 時間真空乾燥後の試料を用いた。

$$
\text { 3. 結果 }
$$

\section{1 土畩埋設試料の外観}

Figure 1 に 3 年間埋設生分解誘引剤添加フィルムの外観 とデジタルマイクロスコープによる写真を示す．形状は， ほぼ初期のままでありながらも表面は，生分解の進行によ り白色化した部分と分解が全く進行せずに透明な状態を保 った部分が認められる. Figure 2 に13年間埋設した生分 解誘引剤添加フィルムの外観を示す。出土したのは埋設当 初のフィルムの一部分のみであり，多くの部分が分解消失 していた. Figure 2に見られるように全体が白色を呈し， 多数の微細な空孔と, 脆弱化が認められ一部は破片化し, 埋設時の形状を保っていない。一方，アルミニウムテープ に覆われて土袞に接触していなかった部分は，初期の形状 を保っていた．残存部分は，分解菌の分布等の状況差異の ために分解進行が遅かった部分と考えられる。

これらの結果は，生分解誘引剂添加がLDPEの生分解に

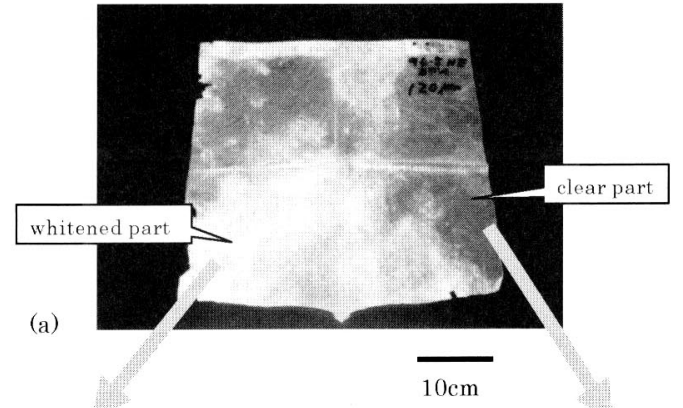

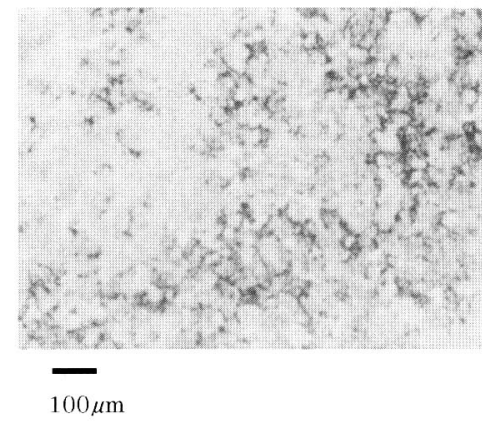

(b)

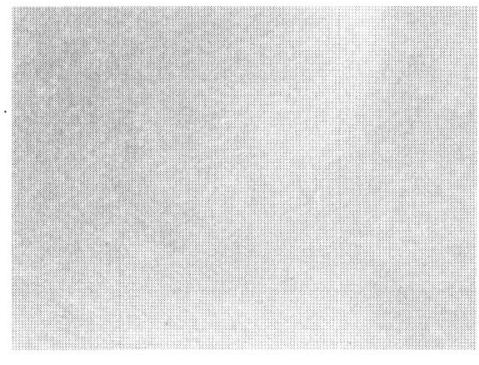

$100 \mu \mathrm{m}$

(c)

Figure 1 Appearance of biodegradation-inducing agents-added LDPE film buried in soil for 3 years.

(a) Appearance of film buried in soil for 3 years.

(b) Observation of whitened part using digital microscope.

(c) Observation of clear part using digital microscope. 


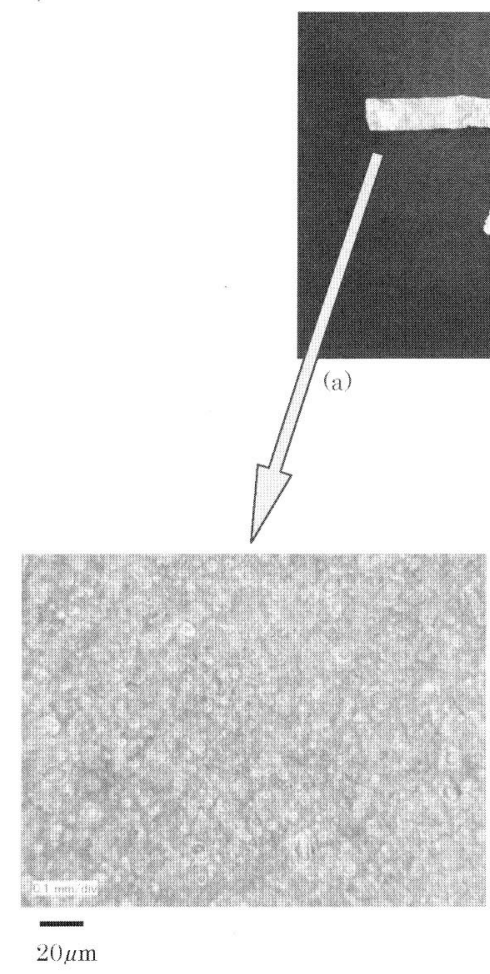

(b)
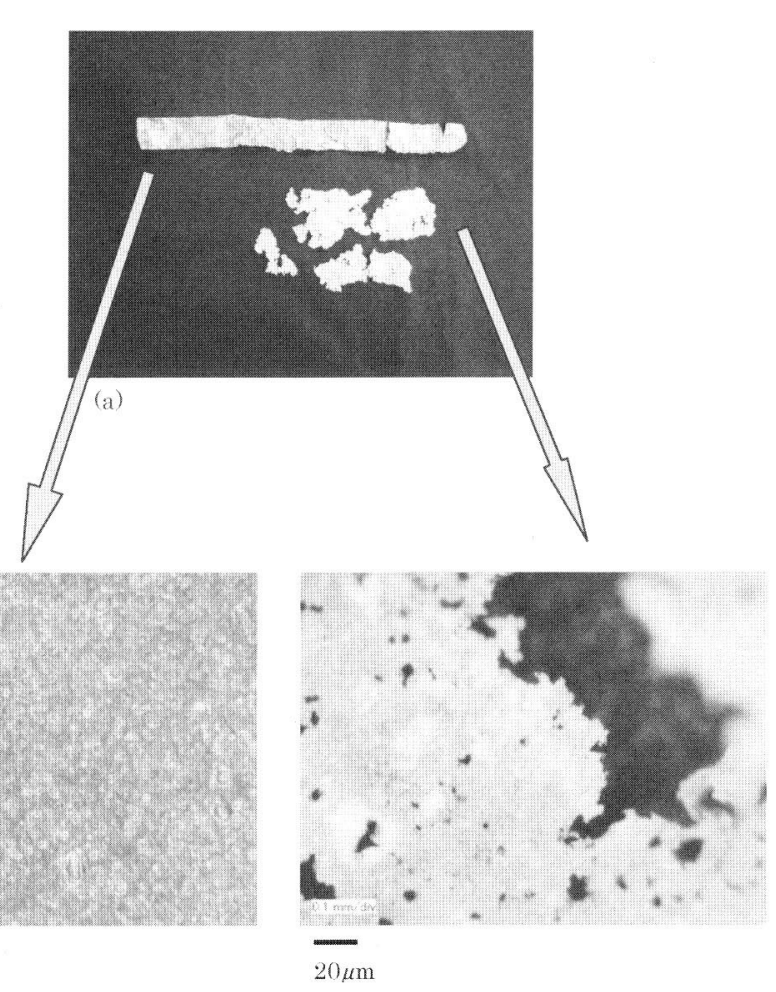

(c)

Figure 2 Appearance of biodegradation-inducing agents-added LDPE film buried in soil for 13 years.

(a) Appearance of film and aluminum tape buried in soil for 13 years.

(b) Observation of the surface uncontacted with soil using digital microscope.

(c) Observation of the surface buried in soil using digital microscope.

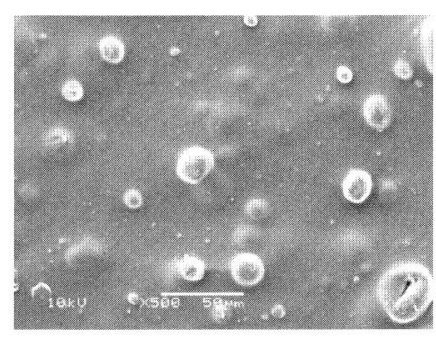

(a) $\times 500$

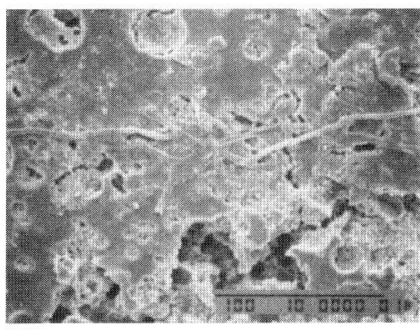

(b) $\times 500$

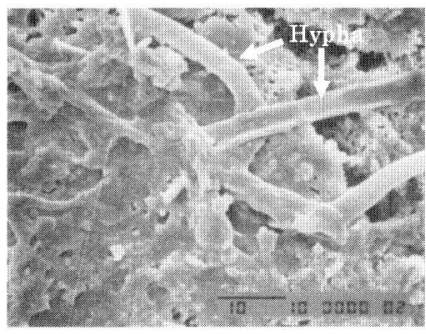

(c) $\times 2000$

Figure 3 SEM images of biodegradation-inducing agents-added LDPE film surface.

(a) Untreated

(b), (c) Buried in soil for 3 years.

非常に有効であることを如実に示している。

\subsection{SEM による表面および断面の観察}

生分解誘引剂添加未処理のフィルムの表面観察写真を Figure $3(\mathrm{a})$ に，3 年間埋設フィルムの白色部の表面観察 写真を Figure 3(b)，（c)に示す. 生分解誘引剤添加未妈 理のフィルムの表面観察写真 (Figure 3(a))には所々に粒 状の凹凸が見られる。 3 年間埋設生分解誘引剂添加フィル ムの白色部表面 (Figure 3(b，c))には糸状菌が付着し，表 面の荒れや多数の空孔が認められる， 3 年間埋設試料の透 明部抢よび白色部の断面写真を Figure 4(a)，（b)にそれ ぞれ示す．断面は，透明部でほとんどダメージが認められ ないのに対して, 白色部では添加剂が一部消失してフィル 厶内部まで分解が進行している. 13 年問埋設生分解誘引
剂添加フィルムを洗浄せずに観察すると, Figure 5(a)に 見られるようにフィルム表面の分解途上の部位において, その形状から Bacillus 属と考えられるコロニーが多数観察 され, 更にフッ化水素酸浸漬処理および蒸留水洗浄後に再 度観察すると, 微生物の体型をフィルム表面に写し出すボ ディーマークがFigure 5(b)に見られるように明瞭に認め られ，分解途上の状況が観察された. Figure 6 に埋設前と 13 年間埋設後の生分解誘引剂添加フィルムの表面, 断面 および試料ステージを $30^{\circ}$ 傾け観察した状態を示す。添加 した生分解誘引郕を起点として, その周囲に分解が拡大さ れ，部分的に欠損も見られる。.上上のSEM観察結果より, 分解初期においては, 生分解誘引剂, 特にでんぷんの存在 部分を中心に系状菌が繁殖し，生分解誘引羭消失により空 
隙が生じ，フィルム表面積が拡大する。添加された酸化植 物油等の働きでLDPEの劣化がすでに進行しているため に，更に酵素分解が加速される。フィルム全体が一様に分 解せずに, 不均一に進行していることから, 添加片の有無,

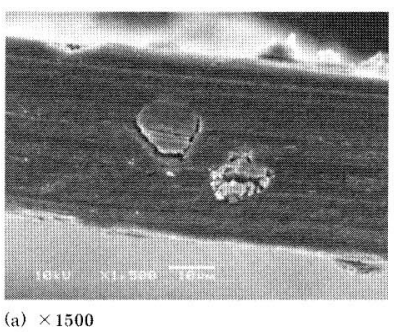

(a) $\times 1500$

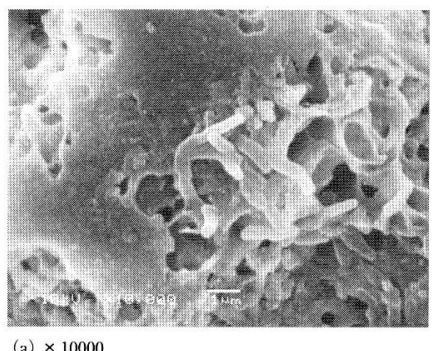

(a) $\times 10000$

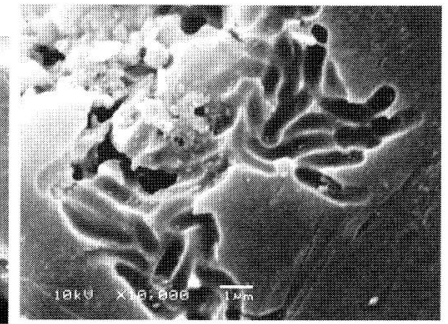

(b) $\times 10000$

Figure 5 SEM images of biodegradation-inducing agentsadded LDPE film surface buried in soil for 13 years $(\times 10,000)$

(a) LDPE compound film surface. The colonies of Bacillus genus.

(b) The LDPE compound film surface washed by $\mathrm{HF}$-aqueous solution. The body marks of Bacillus genus on film surface.
フィルムと土壌の接触状況や接触土壤の成分, 微生物の分 布状況によるコロニーの有無などにより分解の進行速度が 影響されることが明らかとなった。

\section{3 重量変化と分解度}

Table 5 に重量変化と分解度を示す. 生分解誘引剂添加 フィルムの 13 年間土潩埋設による重量減少率は約 $43 \%$ で あることから，単純算出では $100 \%$ 分解するには約 30 年か かることになる. 一方, 無添加フィルムの 13 年間土塞埋 設による重量減少率は約 $5 \%$ であることから，100\%分解 するには約 260 年かかる計算になる。この分解度の算出は, 土壊埋設試験後に残存していた限定された部位に基づいて おり，フィルム表面の脆弱化による物理的な消失も一部含 まれるが, LDPEに生分解誘引剤を添加することにより生 分解が促進され, 劣化・分解速度が著しく増すことが明ら かになった，更には，分解の進行とともにフィルム表面の 荒れが生じ，これら凹凸の生成により表面積が増大するこ とから分解は加速的に進行するものと考えられる.

\section{4 分子量および分子量分布の変化}

測定試料には 13 年間埋設生分解誘引剂添加フィルムの, アルミニウムテープに覆われて土壤に接触していなかった 部分と土壤に接触していた部分 (Figure 2(b)，(c))を用い た. 分子量分布曲線を Figure 7 に, 数平均分子量 $M_{\mathrm{n}}$, 重 量平均分子量 $M_{\mathrm{w}}$, 分子量分布幅の指標である分散指数 $\mathrm{Q}$ 值を Table 6 に示す. 土㙵接触部が非接触部に比べて Figure 7 に示す分子量分布曲線は特に低分子量側にシフトし

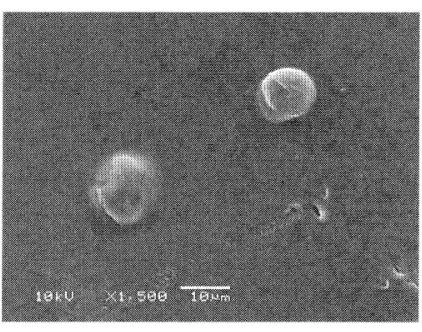

(a) $\times 1500$

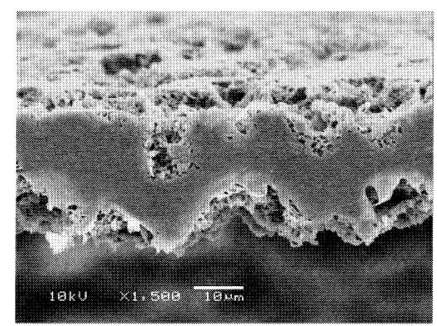

(d) $\times 1500$

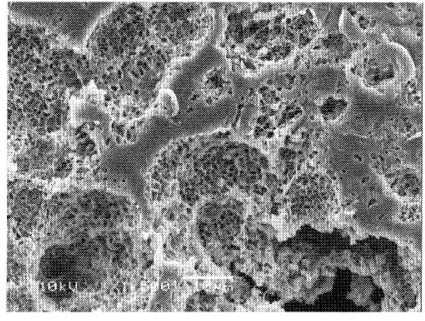

(b) $\times 1500$

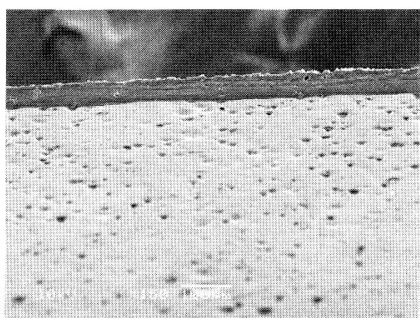

(e) $\times 150$

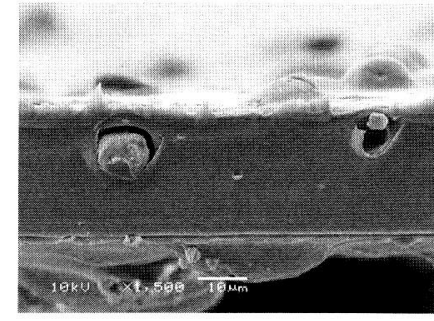

(c) $\times 1500$

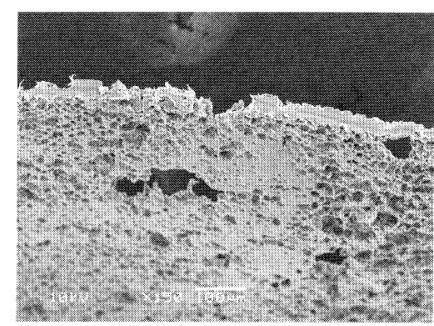

(f) $\times 150$

Figure 6 SEM images of biodegradation-inducing agents-added LDPE film surface and film cross-section and edge part of the film.

(a) LDPE film surface (untreated).

(b) LDPE film surface buried in soil for 13 years.

(c) LDPE film cross-section (untreated).

(d) LDPE film cross-section buried in soil for 13 years.

(e) Edge part of the film (untreated) *

(f) Edge part of the film buried in soil for 13 years*

* Sample stage was tilt 30 degree so that the surface and cross-section could be observed simultaneously. 
Table 5 Comparison of the dry weight between untreated and buried in compost soil

\begin{tabular}{|c|c|c|c|c|c|}
\hline Samples & $\begin{array}{c}\text { No.1 } \\
\text { mg }\end{array}$ & $\begin{array}{c}\text { No.2 } \\
\mathrm{mg}\end{array}$ & $\begin{array}{c}\text { No.3 } \\
\text { mg }\end{array}$ & $\begin{array}{l}\text { Average } \\
\text { mg }\end{array}$ & $\begin{array}{c}\text { Weight } \\
\text { loss rate } \\
\%\end{array}$ \\
\hline Additive-free LDPE / untreated & 1.71 & 1.70 & 1.67 & 1.69 & 0 \\
\hline $\begin{array}{l}\text { Additive-free LDPE buried in } \\
\text { soil for } 13 \text { years }\end{array}$ & 1.61 & 1.59 & 1.62 & 1.61 & 5 \\
\hline $\begin{array}{l}\text { Biodegradation inducing agents } \\
\text { added LDPE / Untreated }\end{array}$ & 3.91 & 3.89 & 3.9 & 3.9 & 0 \\
\hline $\begin{array}{l}\text { Buried in soil for } 3 \text { years } \\
\text { clear part }\end{array}$ & 3.90 & 3.88 & 3.89 & 3.89 & 0 \\
\hline $\begin{array}{l}\text { Buried in soil for } 3 \text { years } \\
\text { whitened part }\end{array}$ & 3.76 & 3.77 & 3.66 & 3.73 & 4 \\
\hline Buried in soil for 13 years & 2.20 & 2.26 & 2.21 & 2.22 & 43 \\
\hline
\end{tabular}

Table 6 Molecular weight of biodegradation-inducing agents-added LDPE buried in soil for 13 years

\begin{tabular}{cccc}
\hline Samples & $\begin{array}{c}\text { Number averaged } \\
\boldsymbol{M}_{\mathrm{n}}\end{array}$ & $\begin{array}{c}\text { Weight averaged } \\
\boldsymbol{M}_{\mathrm{w}}\end{array}$ & $\begin{array}{c}Q \text { value } \\
\boldsymbol{M}_{\mathrm{W}} / \boldsymbol{M}_{\mathrm{n}}\end{array}$ \\
\hline Uncontacted with soil & $1.77 \times 10^{4}$ & $7.96 \times 10^{4}$ & 4.5 \\
Contacted with soil & $1.54 \times 10^{4}$ & $7.78 \times 10^{4}$ & 5.0 \\
\hline
\end{tabular}

ている．土壌接触部では $M_{\mathrm{n}}, M_{\mathrm{w}}$ ともに低下し， $Q$ 值が増 加し分子量分布幅が広がっていることを示している。これ は, LDPEの屋外暴露などの通常の酸化劣化において, 分 子切断による低分子化現象と架橋反応による高分子化現 象 ${ }^{8)}$ を同時に示すこととは異なる分子量変化の挙動であ る.我々は既に 30 年間以上土䁃に埋没していたLDPE製 マヨネーズ容器の高温 GPC 測定で, 高分子量のポリエチ レンの微生物存在下の劣化で直接，分子量の低下を観測し た初めての例を報告した ${ }^{11,12)}$ が，この結果からも生分解 誘引䨩添加高分子量 LDPEフィルムが微生物の関与した劣 化・分解によって 13 年間という比較的短期間で分子量が 低下することが明らかである。

\section{5 顕微FT-IRによる官能基の同定}

生分解誘引剤添加フィルムの埋設前抢よび 3 年間土壤埋 設により白色化した部分の顕微FT-IR スペクトルを Figure 8 に示す. 添加された酸化植物油のエステルのカルボ ニル基に起因する $1745 \mathrm{~cm}^{-1}$ 付近の吸収は，土壤中で分解 もしくはフィルム表面より揮散するため, 土壌埋設処理 3 か月までに減少し，その後ポリマーの酸化劣化に伴うカル ボニル基の増加による吸収が顕著になる ${ }^{1)}$.

3 年間の埋設により, 通常の酸化劣化で生じる 1720 $\mathrm{cm}^{-1}$ 付近のカルボニル基(ケトン㧍よびカルボン酸)の生 成と同時に主鎖中の $-\mathrm{C}=\mathrm{C}-\left(1640 \mathrm{~cm}^{-1}\right)$ ，アルコール由来 の- $\mathrm{OH}$ 変角振動 $\left(1080 \mathrm{~cm}^{-1}\right),-\mathrm{OH}$ 伸縮振動 $\left(3400 \mathrm{~cm}^{-1}\right)$ の顕著な増加が認められた. Figure 9 に 13 年間土壤埋設 生分解誘引剤添加フィルムの土壤接触部と非接触部におけ る顕微FT-IRスペクトルを示す．測定試料は，GPC測定 に用いた同じものである。13 年間埋設土壤接触部では, 3 年間埋設試料で検出された各官能基が更に顕著に検出さ れたのに対して, 土鎄非接触部では酸化植物油で通常の酸

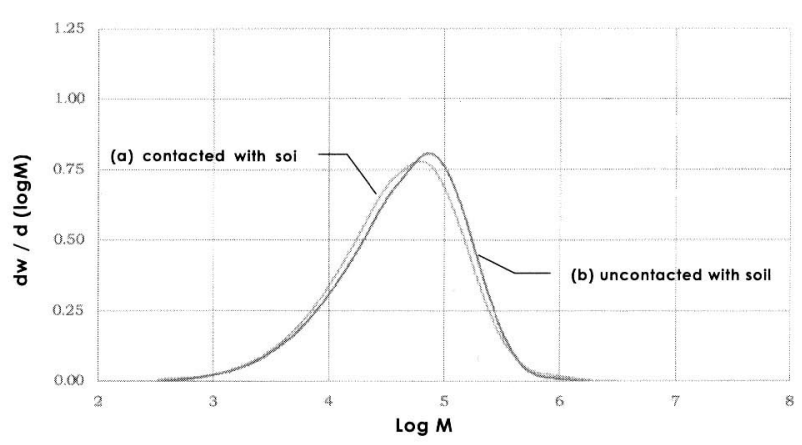

Figure 7 GPC chromatograms of samples buried in soil for 13 years.

(a) Contacted with soil

(b) Uncontacted with soil

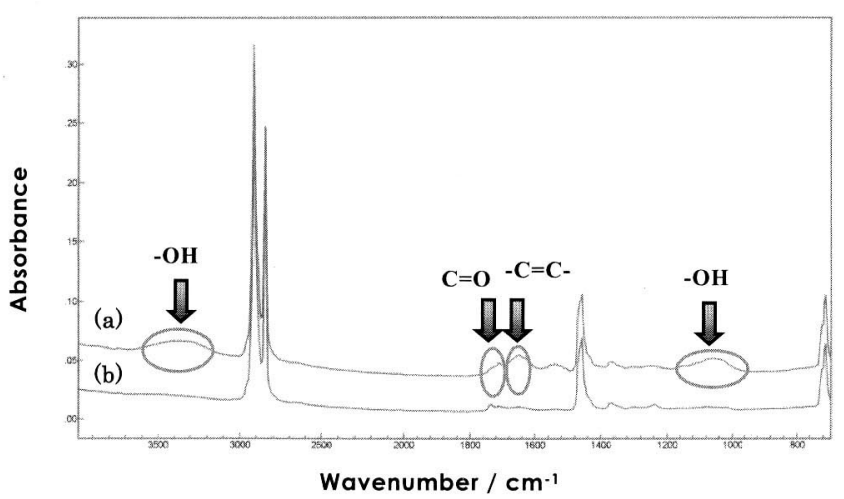

Figure 8 Microscope FT-IR spectra of film surface.

(a) Buried in soil for 3 years / whitened part (b) Untreated

化劣化が加速化されているためにカルボニル基 $\left(1720 \mathrm{~cm}^{-1}\right)$ の生成のみが顕著に現れている。これらの結果より，生分 解誘引剤添加LDPEフィルムは，土㙥に接触していた部分 と接触していない部分では, 酸化劣化の機構に明白な差が あることが明らかである。土袞に接触していた部分は，30 年間以上微生物活性な土壤に埋没していたLDPEフィルム 
と同様の劣化・分解挙動 ${ }^{2)}$ をだることが明らかになっ た. 即ち, 土壌に接触していない部分では通常の酸化劣化 が生じるのに対して，土壤に接触している部分では，劣 化・分解が酸化劣化と微生物分解との複合機構で進行す る.

\section{4. 結論}

生分解誘引剤添加LDPEフィルムは 13 年間の土壌埋設 では, 微生物分解が進行し, フィルム全体が著しい白化現 象を生じて微細な空孔が生成し, 破片化する。採取された 試料は埋設当初の一部分のみであり，多くの部分が消失し ていたことから, 残存していたフィルムは, 土畩との接触 状況, 菌相の分布の違いなどにより分解の進行が比較的遅 かった部分であると考えられる。

フィルム断面の SEM 観察から, 生分解誘引剤の存在部 分を中心に分解が進行して，13年間で土壤接触部におけ る数平均分子量が非接触部と比べると約 $13 \%$ 低下すると ともに，通常の酸化劣化で生じるカルボニル基(ケトンお よびカルボン酸)の生成と同時に主鎖中の-C $=\mathrm{C}-$, アルコ ール由来の- $\mathrm{OH}$ の顕著な増加が認められる. 一方, 土畩 非接触部では添加した酸化植物油による通常の劣化現象の カルボニル基の生成のみが顕著に出現している.すなわち, 土壤に接触している部分と非接触部分では, 酸化劣化の機 構に明白な差異がある。このことから，30年間以上微生 物活性な土壤に埋没していたLDPEフィルム ${ }^{2)}$ と同様の 劣化・分解挙動をたどることが判明した.

生分解誘引剂を添加したLDPEは他の生分解プラスチッ クと比べ，その分解スピードは遅いものの, 分解が著しく 促進され，条件さえ整えば十分に分解することが明らかと なった。

\section{References}

1 ) Ohtake, Y.; Kobayashi, T.; Itoh, S.; Asabe, H.; Yabuki, M.; Murakami, N.; Ono, K.: Nippon Gomu Kyokaishi, 67, 698 (1994)

2 ) Ohtake, Y.; Kobayashi, T.; Itoh, S .; Asabe, H.; Yabuki, M.; Ono, K.: Nippon Gomu Kyokaishi, 66, 504 (1993)

3 ) Ohtake, Y.; Kobayashi, T.; Asabe, H.; Yabuki, M.; Murakami, N.; Ono, K.: Nippon Kagakukaishi, 4, 325 (1996)

4) Watanabe, T.; Ohtake, Y.; Asabe, H.; Murakami, N.; Koyama, F.; Ohmura, H.; Furukawa, M.: Nippon Gomu Kyokaishi, 80, 409 (2007)

5 ) Machado, A.V.; Moura, I.; Duarte, F.M.; Botelho, G.; Nogueira, R.; Brito, A.G.: Int. Polym. Process., 22, 512 (2007)

6) Nath, M.; Shenoy, M.A.; Kale, D.D.: J. Polym. Mater., 24, 163 (2007)

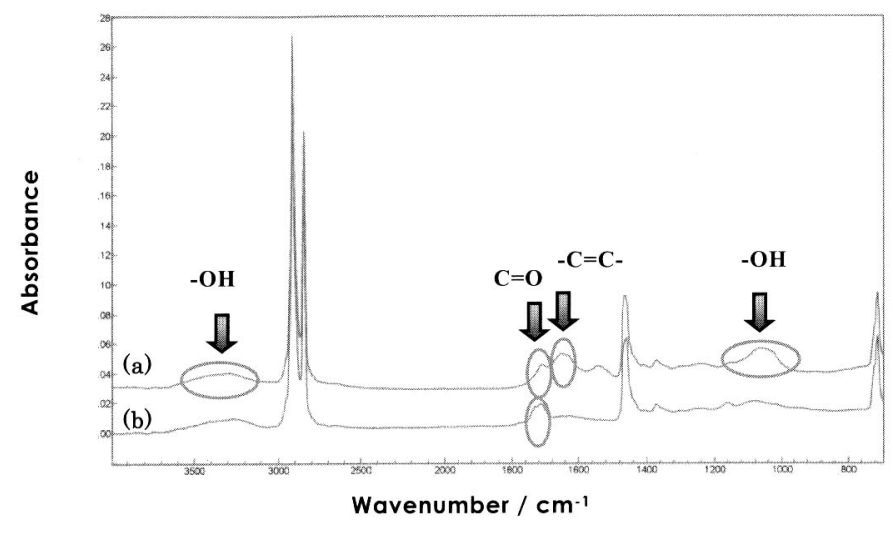

Figure 9 Microscope FT-IR spectra of film surface buried in soil for 13 years.

(a) Contacted with soil

(b) Uncontacted with soil

7 ) Tarres, A.V.; Zamudio-Flares, P. B.; Salgado- Delgado, R.; BelloPerez, L. A.: J. Appl. Polym. Sci., 106, 3994 (2007)

8 ) Rosa, D. S.; Gaboardi, F.; Duedes, C. G. F.; Calil, M. R.: J. Materi. Scie., 42, 8093 (2007)

9 ) Jakubowicz, I.: Polym. Degrad. Stab., 80, 39 (2003)

10) Khabbaz, F.; Albertsson, A.C.: J. Appl. Polym. Sci., 79, 2309 (2001)

11) Ohtake, Y.; Gomi, Y.; Kobayashi, T.; Itoh, S.; Hyakutake, K.; Yabuki, M.: Nippon Gomu Kyokaishi, 64, 677 (1991)

12) Ohtake, Y.; Kobayashi, T.; Gomi, Y.; Itoh, S.; Hyakutake, K.; Yabuki, M.: Nippon Gomu Kyokaishi, 64, 688 (1991)

13) Ohtake, Y.; Kobayashi, T.; Itoh, S.; Asabe, H.; Yabuki, M.; Murakami, N.; Ono, K.: Nippon Gomu Kyokaishi, 67, 636 (1994)

14) Ohtake, Y.; Kobayashi, T.; Asabe, H.; Murakami, N.; Ono, K.: $J$. Appl. Polym. Sci., 56, 1789 (1995)

15) Ohtake, Y.; Kobayashi, T.; Itoh, S.; Asabe, H.; Yabuki, M.: Ono, K.: Nippon Gomu Kyokaishi, 66, 756 (1993)

16) Ohtake, Y.; Kobayashi, T.; Asabe, H.; Murakami, N.; Ono, K.: $J$. Appl. Polym. Sci., 70, 1643 (1998)

\section{日本語表記参考文献}

1 ）大武義人，小林智子，伊藤茂樹，浅部仁志，矢吹増男，村上信 直，小野勝道：日本ゴム協会誌，67，698（1994）

2 ）大武義人，小林智子，伊藤茂樹，浅部仁志，矢吹増男，小野勝 道：日本ゴム協会誌，66，504（1993）

3 ) 大武義人, 小林智子, 浅部仁志, 矢吹増男, 村上信直, 小野勝 道：日本化学会誌，4，325（1996）

4) 渡邊智子, 大武義人, 浅部仁志, 村上信直, 小山文夫, 大村浩, 古川睦久：日本ゴム協会誌，80，409（2007）

11）大武義人, 五味洋子, 小林智子, 伊藤茂樹, 百武健一郎, 矢吹 増男：日本ゴム協会誌, 64, 677 (1991)

12）大武義人, 小林智子, 五味洋子, 伊藤茂樹, 百武健一郎, 矢吹 増男：日本ゴム協会誌，64，688（1991）

13）大武義人，小林智子，伊藤茂樹，浅部仁志，矢吹增男，村上信 直，小野勝道：日本ゴム協会誌，67，636 (1994)

15）大武義人, 小林智子, 伊藤茂樹, 浅部仁志, 矢吹増男, 小野勝 道：日本ゴム協会誌，66，756（1993） 